\section{Diagnostikk av koronararteriestenoser ved transtorakal Doppler ekkokardiografi}

Johnny Vegsundvåg disputerte for ph.dgraden ved Norges teknisk-naturvitenskapelige universitet den 26. februar 2015 med avhandlingen „Transthoracic Doppler echocardiography in examination of coronary artery flow. Methodological and functional aspects“.

Koronararteriesykdom er en av hovedårsakene til sykdom og død. Målet av doktorgradsarbeidet var, å undersøke hvor egnet transtorakal ekkokardiografi (TTE) er til påvisning av koronararteriene og koronararteriesykdom.

Studiegruppen bestod av 111 pasienter, som skulle til koronarangiografi på grunn av mistenkt eller påvist koronarsykdom.
Flere undersøkelser har vist, at mange koronararterielesjoner, som viser anatomisk signifikant stenose, ikke har funksjonell betydning. Disse bør etter dagens retningslinjer ikke blokkes ut. TTE med reduksjon av coronar flow reserve (CFR) kan vise, at en anatomisk signifikant koronararteriestenose har funksjonell betydning. Hos de 108 med koronarangiografi kartlagte pasientene kunne CFR måles $\mathrm{i}$ hhv. LAD, Cx og RCA hos hhv. 97, 63 og 75 $\%$ av pasientene. Bare halvparten av de moderate, men de fleste høygradige koronararteriestenosene var av funksjonell betydning.

I samme pasientgruppen kunne videre vises, at profilendring av venstre koronarar-

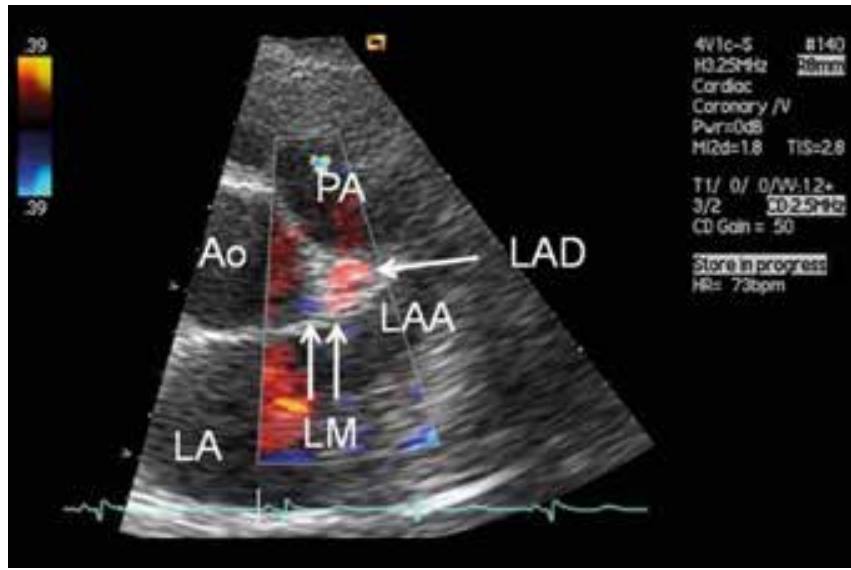

I modifisert short-axis snitt kommer venstre hoved koronararterie (LM) fra venstre Valsalva sinus og fortsetter som venstre nedgående koronararterie $(\mathrm{LAD})$. Ao = aorta; $\mathrm{LA}=$ venstre atrium; $\mathrm{LAA}=$ venstre atrium appendix auricularis; PA = arteria pulmonalis.

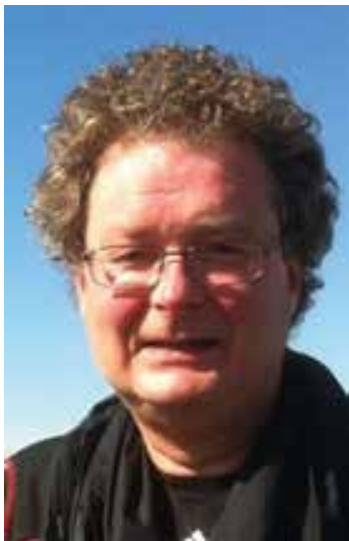

Johnny Vegsundvåg

Hos 108 (98\%) av disse pasientene kunne TTE fremstille hele venstre hovedstamme, venstre nedgående koronararterie (LAD) og proksimale venstre circumflexa koronararterie (CX), mens øvrige deler av $\mathrm{Cx}$ og høyre kransarterie (RCA) ble mindre fullstendig avbildet. teriens flow kan være en enkel metode for påvisning av anatomisk eller funksjonelt signifikante koronarstenoser. Ved å påvise retnings- og hastighetsendringer av koronararteriens flow ved TTE ble 25 av 28 okklusjoner diagnostisert.

Oppsummerende viser avhandlingen, at transtorakal ekkokardiografi er et viktig ledd i diagnostikk og vurdering av koronararteriestenoser. 